\section{ウェブクランプ形式柱梁接合部 の製作時間の実態調査}

\section{FIELD STUDY OF FABRICATION TIME FOR WEB-CLAMPED BEAM-TO- COLUMN CONNECTION}

\author{
荒木景太 \\ 伊山 潤 \\ $* 2$ \\ キーワード : \\ ウェブクランプ形式柱梁接合部，時間研究，動作研究，製作時間
}

Keywords: Fabrication time
Web-clamped beam-to-column connection, Time study, Motion study,
Welded beam-to-column connections have been widely used in Japan, however, one of the disadvantage compared to bolted connections is the difficulty and low production speed. Bolted connection may be an alternative way to higher production speed, however, very few quantitative and actual data have been reported.

This paper reports the fabrication time for web-clamp type connections as one of the bolted connections. From the work record for an actual steel building construction using the Web-clamped type connections, the work time of each production step was aggregated and compared to that of conventional welded connections. As a result, it was shown that the fabrication time for Web-clamped connections is $30 \%$ less than the estimated fabrication time for conventional welded connection, thanks to the smaller number of parts and the less quantity of welding.

\section{1. はじめに}

柱と梁を主にボルトにより接合する乾式柱梁接合工法は、シート アングル形式、スプリットティ形式、ベースプレート形式など、さ まざまな方法があり ${ }^{1)}$ 、本報で扱うウェブクランプ形式柱梁接合部 ${ }^{21}$ (図 1(a))もこの分類のひとつとして位置づけられる。これらの乾式柱 梁接合工法は、シートアングル等の接合金物を介して柱と梁を現場 でボルト接合するため、柱の溶接量が少なく、超音波探傷試験 (UT) も省略可能なため、製作から建方までの工程が少ないことが指摘さ れている ${ }^{3)}$ 。また柱の輸送の際も、従来の溶接柱梁接合部は工場で溶 接接合した梁ブラケットが柱から飛び出た状態で工事現場まで輸送 するのに対し、上記の乾式柱梁接合工法ではほぼ形鋼ままの柱部材 を工事現場に輸送するため、トラックの積載効率がよく効率的な輸 送が可能であることが指摘されている ${ }^{3), 4)}$

しかし上記の利点がありながら、わが国ではシステム建築を除く 鋼構造建築物においてこれらの接合部の採用が少ないのが現状であ る5)。この理由のひとつとして、わが国の鉄骨加工工場の多くが完全 溶込み溶接を用いた柱梁接合構造を前提とした生産ラインを整えて いることが挙げられる。多くの鉄骨加工工場では完全溶込み溶接の 施工に専用の産業用ロボットを用いて行うのに対して、上記の乾式 柱梁接合工法は隅肉溶接が主であるため、溶接は作業者により行わ れる。省溶接であるといっても、このような製作方法の違いがある ため、上記の乾式柱梁接合工法にかかる接合部製作時間が不明確と なっており、それが乾式柱梁接合工法の採用の妨げの一因となって いる。

しかし上記の問題意識のもと、接合部の製作時間を比較し、工法 や製作方法の合理性を定量的に比較した検討は極めて少ない。たと えば崔ら》は従来溶接形式柱梁接合部と嵌合式接合部の生産性を示す 指標の一つとして溶接にかかる時間に着目し、いくつかの試験体を 製作してその溶接にかかった時間を比較している。しかし接合部の

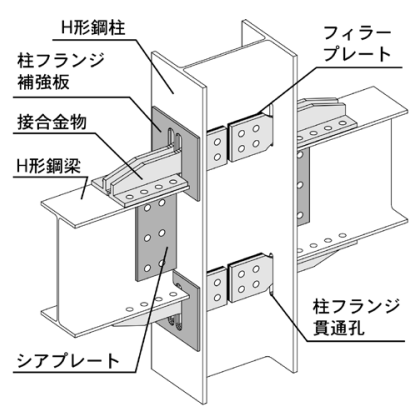

(a) ウェプクランプ形式柱梁接合部概要

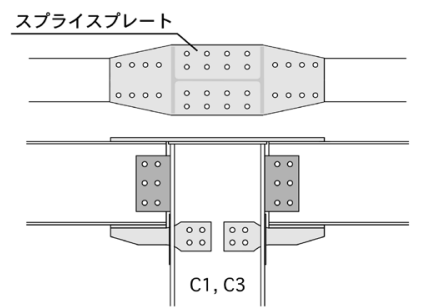

(c-1) R階 両側梁

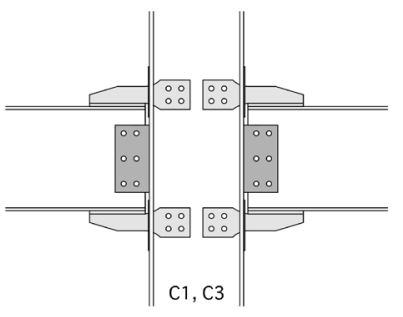

(d-1) 2階 両側梁

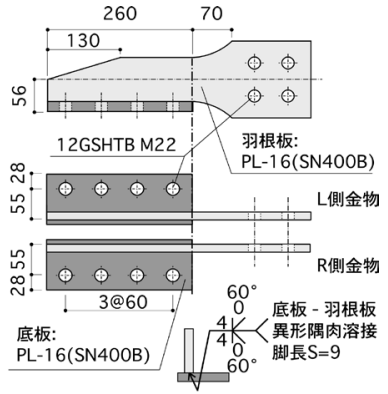

(b) 接合金物 (1セット)概要

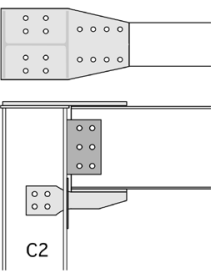

（c-2）R階片側梁

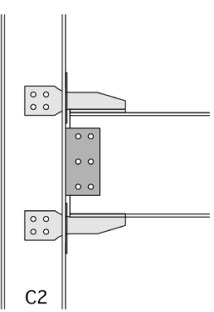

(d-2) 2階片側梁
図 1 対象物件で用いたウェブクランプ形式柱梁接合部概要

製作は工場内での作業のみを取り上げても、一次加工や組立、検査 などを含むため、その製作時間は溶接のみで決まるわけではない。

そこで本報では、より実態に即した接合部製作時間を把握し、柱 梁接合部製作における乾式柱梁接合工法の特徴を把握するため、乾 
式柱梁接合工法の一つに位置づけられるウェブクランプ形式柱梁接 合部を用いた実績物件の製作記録を調査し、建物全体の柱梁接合部 について、鋼板加工から溶接・検査に至るまでの製作各工程の作業 時間を算出した。さらに同物件と同条件の架構を角形鋼管柱を用い た従来溶接形式柱梁接合部を用いて再設計し、その場合の接合部の 製作に予想される時間を算出した。これら両接合部の製作時間の比 較を通じ、柱梁接合部の製作において、ウェブクランプ形式柱梁接 合部がどのような特徵があるかを考察した。

なお本報では従来溶接形式柱梁接合部として、梁ブラケットを工 場で溶接接合する方式を採用している。この場合、梁の製作につい てはウェブクランプ形式柱梁接合部と従来溶接形式柱梁接合部で違 いはないため、本報では特に柱（従来溶接形式柱梁接合部ではブラ ケットの接合までを含む）の製作に注目して検討を行った。

\section{2. ウェブクランプ形式柱梁接合部を用いた実施物件の概要}

\section{1 建物概要}

3 階建て鉄骨造による自走式立体駐車場である。図 2 には概略平面 図を示す。およそ $110 \mathrm{~m} \times 50 \mathrm{~m}$ の本体棟に、エクスパンションジョイ ントで分離されたスロープが付随した形式となっているが、本報で は本体棟のみを検証対象とする。本建物ではブレースを用いず、 $\mathrm{H}$ 形鋼柱断面の強軸方向を変えて短辺および長辺方向にラーメン構造 を形成し、水平力を負担する構造計画としている。

図 3 および表 1 には柱梁断面の配置とサイズを示す。主要な柱は 2 階と R 階ともに H-390×300×10×16、梁は 2 階が H-450×200×9×14、R 階が H-396×199×7×11 で、いずれも JIS 規格の H 形鋼である。柱梁接 合部の概要を図 1 に示す。同図に示すように、本柱梁接合部は接合 金物とシアプレートで H 形鋼柱梁を接合する工法で、本物件で用い る接合金物の形状は柱梁断面サイズにかかわらず同図(b)に示す 1 種 類である。また表 1 に示すように、その他柱梁接合に使用する補強 板類、シアプレートも柱梁断面にかかわらず同形状に設計している。 接合部は図 1 に示すように、2 階であれば上下フランジを接合金物で 接合し、R 階であれば上フランジをスプライスプレート、下フラン ジを接合金物で接合する形式となる。駐車場であるため、溶融亜鉛 めつきを施している。ボルト本数の低減のため、柱と接合金物の接 合には超高力ボルト $(12 \mathrm{G}$ 溶融亜鉛めっき高力ボルト)を使用した。 $12 \mathrm{G}$ 溶融亜鉛めっき高力ボルトは F14T 相当の超高力ボルトに溶融亜 鉛めっき処理を行っており、メッキボルトでありながら F12T 相当の 張力導入を可能としたものである。接合金物は、図 1(b)に示した L 側金物と $\mathrm{R}$ 側金物の 2 ピースを 1 セットとしてカウントし、梁の上 フランジと下フランジとにそれぞれ 1 セットずつ使用する。図 3 に示 す $\mathrm{C} 1$ と C 3 は両側に梁が取り付く柱で、R 階で図 1(c-1)、2 階で図 1(d-1)のようなディテールとなるため、柱一本あたりに使用する接合 金物は6セット、 $\mathrm{C} 2$ は隅柱で、その接合部は $\mathrm{R}$ 階で図 1(c-2)、2 階で 図 1(d-2)となるため、使用する接合金物は 3 セットである。本物件で 用いた接合金物は計 648 セットである。

\section{2 柱に設けるウェブクランプ形式柱梁接合部の製作概要}

図 3 に示した柱 $\mathrm{C} 1$ に設けるウェブクランプ形式柱梁接合部の製作 概要を図 4 に示す。本報で示した柱 $\mathrm{C} 1$ 〜 3 に設けるウェブクランプ 形式柱梁接合部の製作方法は共通しており、その概要は以下である。 まず、柱を所定の長さに切断したのち、柱ウェブに接合金物接合

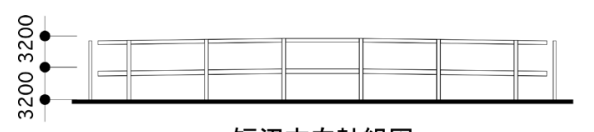

短辺方向軸組図

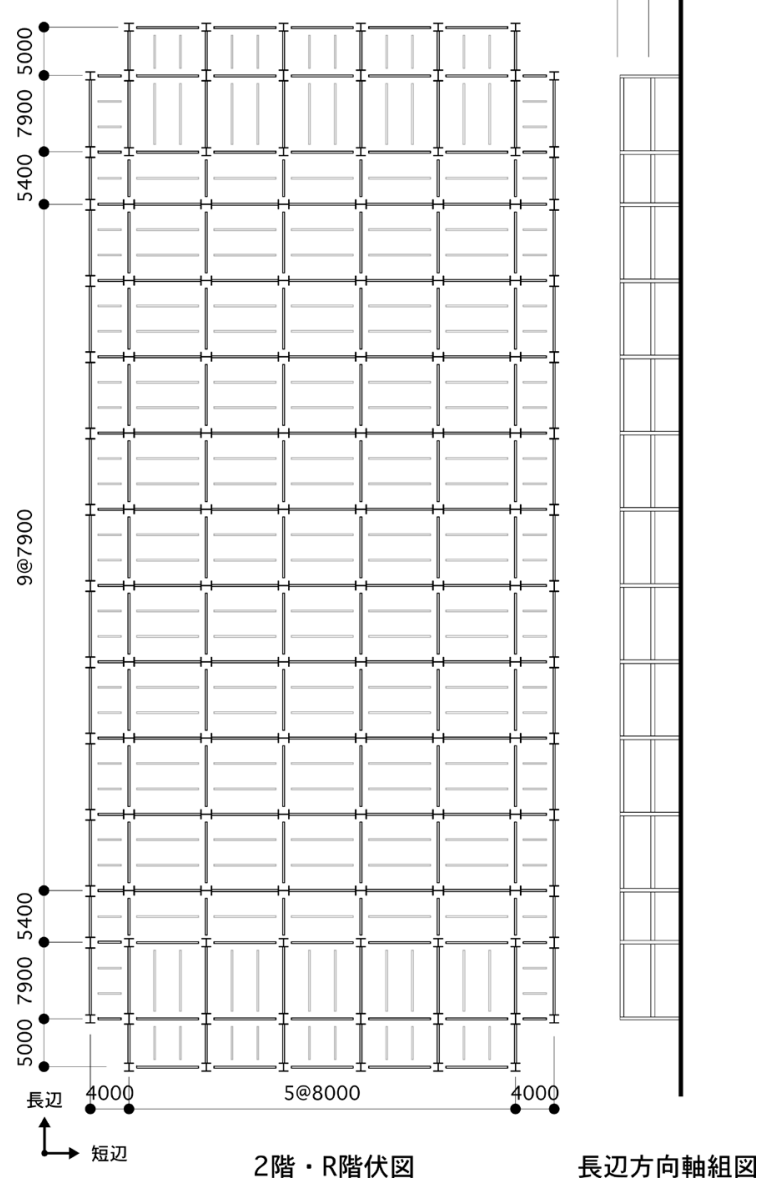

図 2 対象物件概要

用のボルト孔を設ける。これらの加工は従来溶接工法と同様に、 $\mathrm{NC}$ 制御による切断・孔あけ加工機および開先機により行われる。次に 柱フランジに接合金物貫通用の長孔を設ける。この加工は、従来溶 接工法にはない本工法に特有のものであるが、 $\mathrm{NC}$ 制御による自由形 状の鋼板切断が可能なポータブルガス切断機にて行った。

その後、別途製作しておいた柱フランジ補強板を隅肉溶接により 柱フランジ面に接合する。この隅肉溶接は作業者による半自動溶接 にて行われ、補強板外周だけでなく長孔内側にも施す。最後に、柱 フランジには梁ウェブ接合用のシアプレートを、柱ウェブには直交 梁接合用のガセットプレートをそれぞれ溶接して柱の製作は完了す る。

溶接検査については、本工法では図 1 に示した 2 階と R 階の柱梁 接合部の製作はすべて隅肉溶接または部分溶込み溶接にておこなわ れるため、超音波探傷試験（UT）を行わず外観検査を行うのみとし ている。ただし柱脚部は通常の工法で設計しており、製作ではべー スプレートと H 形鋼柱を完全溶込み溶接にて接合するため、この部 分でUTを行った。

ウェブクランプ工法と従来溶接工法とを比較すると、2 階と R 階に 設ける柱梁接合部ディテールが大きく異なるが、柱脚部はほぼ同形 状である。このため本報では 2 階と R 階の柱梁接合部分に関する製 作時間の算出・比較のみを行っている。 


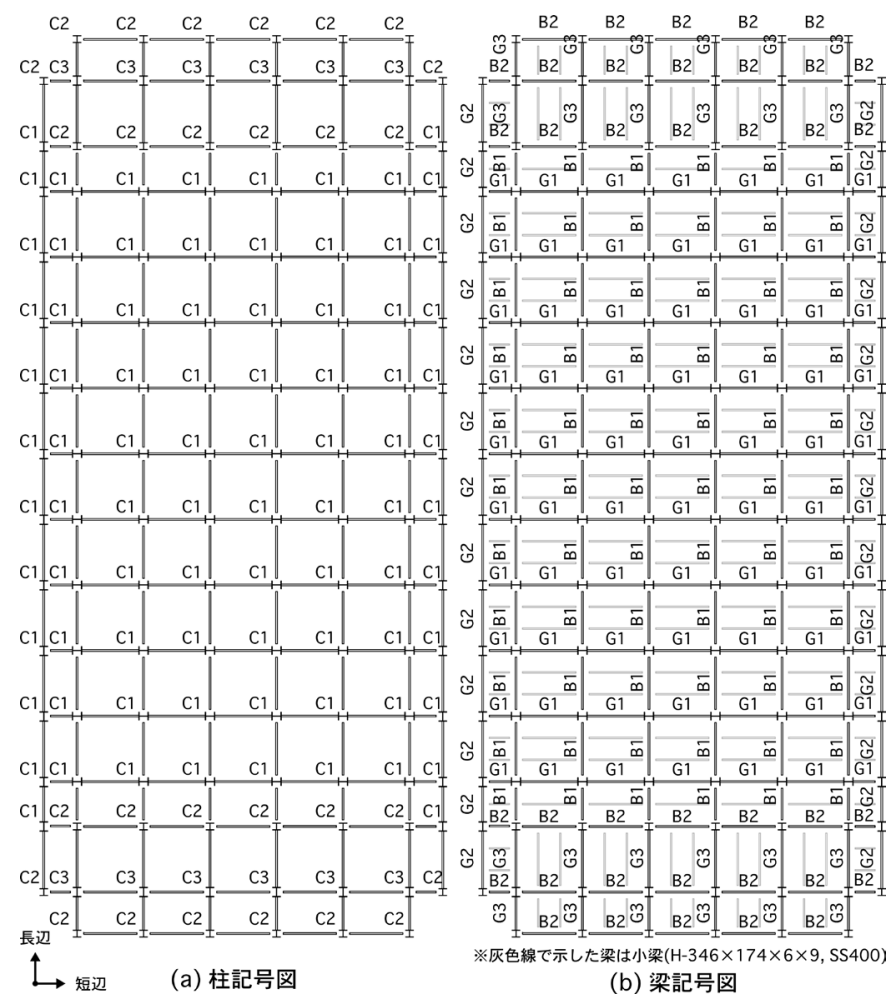

図 3 ウェブクランプ形式 - 柱梁部材概要

\section{3 接合金物製作の概要}

接合金物は前述のようにおよそ 650 セット必要である。これを短 期間で生産するために、 NC 加工機およびロボットによる大量生産を 行った。まず鋼板をガス切断し孔あけ加工を行うが、これらの加工 はいずれも $\mathrm{NC}$ 制御による専用機械で行った。次に羽根板と底板を部 分溶け込み溶接により接合するが、その開先加工および溶接は汎用 の産業用多関節ロボットを用いて行われ、一定品質の接合金物が大 量自動生産されるようにした。

\section{4 梁製作の概要}

ウェブクランプ形式柱梁接合部では、柱側にブラケットが必要な いため、ブラケットを用いる従来溶接形式柱梁接合部とは梁長さが 異なる。しかし、梁製作については従来溶接柱梁接合部の場合と同 様、梁を所定の長さに切断した後、梁フランジおよびウェブに継手 接合用の孔を空ける、という工程により製作される。このため梁の 製作時間は従来溶接柱梁接合部と違いがないと考えられるため、本 報告では梁製作については検討対象外とした。

\section{3. 従来溶接形式柱梁接合部を用いて建物を再設計した場合 \\ 3.1 建物概要}

前章の対象物件を従来溶接形式柱梁接合部を用いて設計する場合、 角形鋼管柱を用いた両方向ラーメンとして設計するのが一般的であ る。これは角形鋼管柱を用いると両方向ラーメン架構を容易に構成 できること、また多くの鉄骨加工工場が角形鋼管柱に代表される閉 断面の溶接を前提としたロボット溶接設備を保有しており人手をか けなくても溶接が可能であるといった理由によるものである。本章 では、一般的な従来溶接形式柱梁接合部とウェブクランプ形式柱梁 接合部の製作時間の比較を行うために、前章の対象物件をブラケッ トを有する角形鋼管柱を想定して再設計し、この場合に柱梁接合部 の製作に要する時間を算出する。従来溶接形式柱梁接合部による対
表 1 ウェブクランプ形式 - 柱梁部材断面概要

\begin{tabular}{|c|c|c|c|}
\hline \multirow{2}{*}{ 部材 } & \multirow{2}{*}{ 記号 } & \multicolumn{2}{|c|}{ 断面 } \\
\hline & & 2 階 & R 階 \\
\hline \multirow{3}{*}{ 柱 } & $\mathrm{C} 1$ & \multicolumn{2}{|c|}{ H-390x300x10x16(SM490A) } \\
\hline & $\mathrm{C} 2$ & \multicolumn{2}{|c|}{ H-300x300x10x15(SM490A) } \\
\hline & $\mathrm{C} 3$ & \multicolumn{2}{|c|}{$\mathrm{H}-440 \times 300 \times 11 \times 18(\mathrm{SM} 490 \mathrm{~A})$} \\
\hline \multirow{5}{*}{ 梁 } & G1 & $\mathrm{H}-450 \times 200 \times 9 \times 14(\mathrm{SS} 400)$ & \multirow{3}{*}{ H-396x199x7x11(SS400) } \\
\hline & G2 & \multirow{2}{*}{$\mathrm{H}-496 \times 199 \times 9 \times 14(\mathrm{SS} 400)$} & \\
\hline & G3 & & \\
\hline & B1 & \multirow{2}{*}{\multicolumn{2}{|c|}{$\mathrm{H}-446 \times 199 \times 8 \times 12(\mathrm{SS} 400)$}} \\
\hline & B2 & & \\
\hline \multirow{3}{*}{ 接合部 } & フランジ補強板 & \multicolumn{2}{|c|}{ PL-6(SM490A) } \\
\hline & シアPL & \multicolumn{2}{|c|}{ PL-12(SS400) } \\
\hline & 接合金物 & \multicolumn{2}{|c|}{ 図 1(b)に示す 1 種類(SN400B) } \\
\hline
\end{tabular}

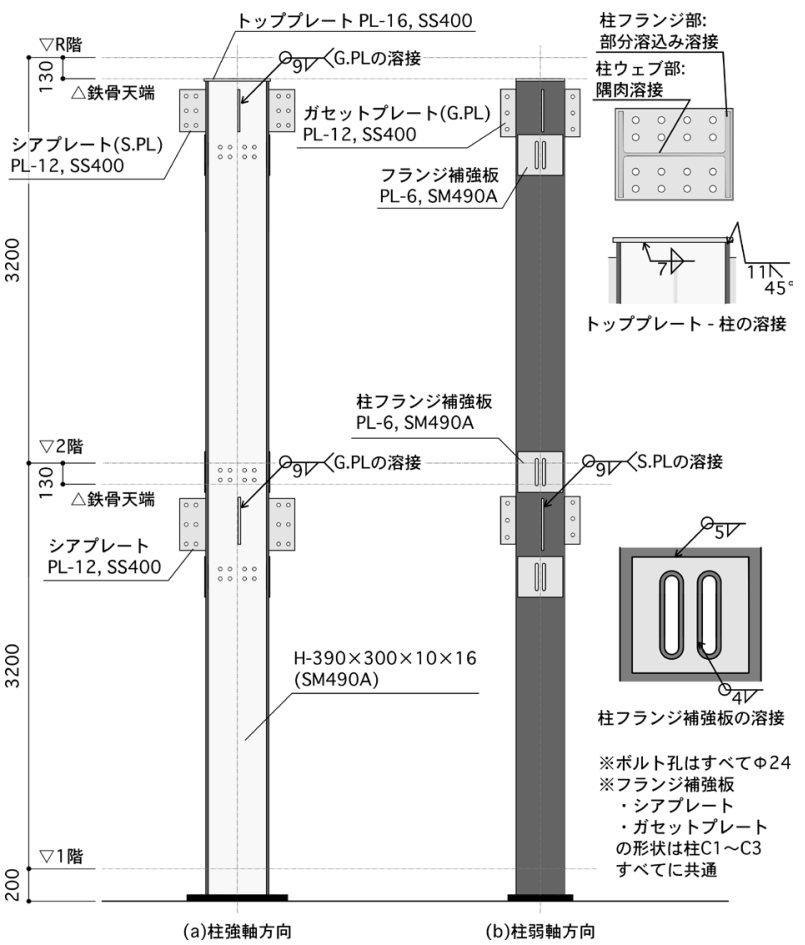

図 4 柱 $\mathrm{C} 1$ に設けるウェブクランプ形式柱梁接合部の概要

象物件の設計と柱製作の概要を以下に示す。

図 5 と表 2 には、従来溶接形式柱梁接合部で設計した場合における 柱梁部材配置、および柱梁断面の概要を示す。前述のウェブクラン プ柱梁接合部を用いた場合と同様にブレースを用いず、角形鋼管柱 を用いて長辺および短辺方向にラーメン構造を形成し水平力を負担 する構造計画とした。この場合はすべての構面が両方向ラーメンに なっており、この点ではウェブクランプ形式柱梁接合部を用いた設 計と異なる。

設計条件は前章に示したウェブクランプ形式柱梁接合部を用いた 場合となるべく同条件とするため以下とした。まず各階荷重はウエ ブクランプ工法の場合と同じに設定し、その条件で許容応力度設計 および保有水平耐力計算を行った。部材断面の決定の際は、ウェブ クランプ工法の実施物件では調達の容易さを考えて JIS 規格の H 形断 面を想定したため、従来溶接形式柱梁接合部を用いるの場合におい ても調達の容易さを重視することにし、梁には JIS 規格 H 形鋼を、柱 にはロール成形角形鋼管を用いる設計とした。

表 3 には、図 3 で示したウェブクランプ形式柱梁接合部を用いた場 合と図 5 で示した従来溶接形式柱梁接合部を用いた場合をもとに、 


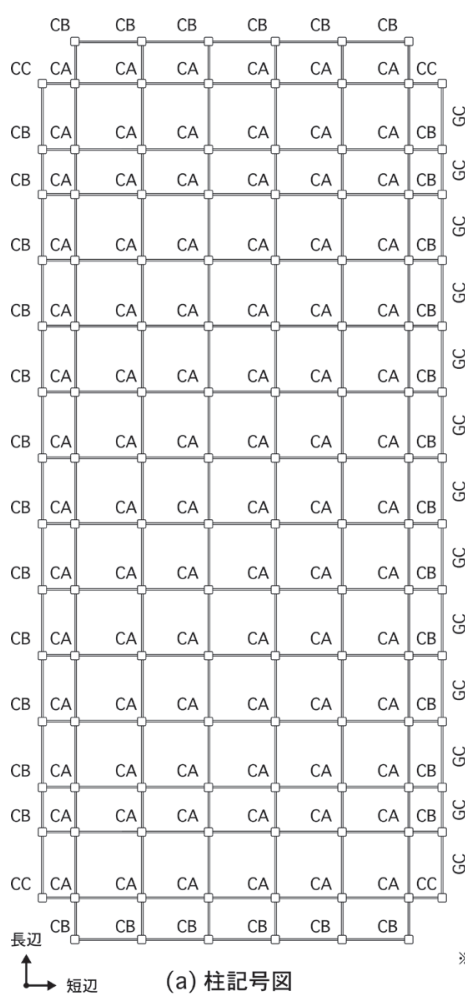

図 5 従来形式 - 柱梁部材概要

柱梁ピース数および建物全体重量を算出したものである。表中の柱 および大梁のピース数は表 1 および表 2 で示した部材ピース数を示し たもので、小梁は図 3 および図 5 において灰色線で示した部材ピース 数を示した。建物全体重量はウェブクランプ形式柱梁接合部を用い た場合は柱、梁、補強板・ガセットプレート類、および接合金物の 重量の合計であるのに対し、従来溶接形式柱梁接合部を用いた場合 はそれに対応する重量として、柱、梁、ダイアフラムおよびスプラ イスプレートの重量の合計を示した。同表をみると、各部材のピー 又数および建物全体重量はウェブクランプ形式と従来溶接形式でほ ぼ同じである。

\section{2 柱に設ける従来溶接形式柱梁接合部の製作概要}

図 5 に示した柱 CA に設ける従来溶接形式柱梁接合部の製作概要を 図 6 に示す。本報で想定したのは、角形鋼管柱に柱通しダイアフラ ムを設けて、梁ブラケットを溶接接合する方式である。同図には柱 $\mathrm{CA}$ を代表として示したが、柱 $\mathrm{CA} \sim \mathrm{CC}$ に設ける従来溶接形式柱梁接 合部の製作方法は共通しており、その概要は以下である。

まず柱および梁ブラケットを所定の長さに切断し開先加工を行う。 これらはそれぞれ専用の加工機により、切断から開先加工までを自 動的に行われることを想定している。次に、柱パネル部分と上下の 通しダイアフラムを組立・溶接してコア部分を製作し、その後コア 部分に梁ブラケットを組立・溶接する。最後に梁ブラケットが取り 付いたコア部分と柱部材(シャフト)を組立・溶接し完了する。柱とダ イアフラムの溶接(コア溶接・柱コアとシャフトの大組溶接)は専用の ロボットによる溶接、柱コアと梁ブラケットの溶接(仕口溶接)は作業 者による半自動溶接にて行うことを想定した。

検査については、柱、梁ブラケットおよびダイアフラムの取り付 けはそれぞれ完全溶込み溶接を行うため、すべての完全溶込み溶接 でUT と外観検査を行うこととし、この時間を算出している。
表 2 従来形式 - 柱梁部材断面概要

\begin{tabular}{|c|c|c|c|}
\hline \multirow{2}{*}{ 部材 } & \multirow{2}{*}{ 記号 } & \multicolumn{2}{|c|}{ 断面 } \\
\hline & & 2 階 & $\mathrm{R}$ 階 \\
\hline \multirow{3}{*}{ 柱 } & $\mathrm{CA}$ & $\square-300 \times 300 \times 12(B C R 295)$ & $\square-300 \times 300 \times 9$ (BCR295) \\
\hline & $\mathrm{CB}$ & \multirow{2}{*}{\multicolumn{2}{|c|}{$\square-300 \times 300 \times 9$ (BCR295) }} \\
\hline & $\mathrm{CC}$ & & \\
\hline \multirow{3}{*}{ 梁 } & GA & $\begin{array}{c}\text { H-450x200x9x14 } \\
\text { (SS400, ブラケット SN400B) }\end{array}$ & $\begin{array}{c}\text { H-396x199x7x11 } \\
\text { (SS400, ブラケット SN400B) }\end{array}$ \\
\hline & GB & $\begin{array}{c}\text { H-450x200x9x14 } \\
\text { (SM490A, ブラケット SN490B) }\end{array}$ & $\begin{array}{c}\text { H-400x200x8x13 } \\
\text { (SM490A, ブラケット SN490B) }\end{array}$ \\
\hline & GC & $\begin{array}{c}\text { H-450x200x9x14 } \\
\text { (SM490A, ブラケット SN490B) }\end{array}$ & $\begin{array}{c}\text { H-396x199x7x11 } \\
\text { (SS400, ブラケット SN400B) }\end{array}$ \\
\hline \multirow{2}{*}{ 接合部 } & ダイアフラム & \multicolumn{2}{|c|}{ PL-19(SN490B) } \\
\hline & スプライス PL※ & フランジ:2PL-1 & ウェブ: 2PL-9 \\
\hline
\end{tabular}

表 3 設計重量の比較

\begin{tabular}{|c|c|c|c|c|}
\hline 使用接合部 & 柱(台) & 大梁(台) & 小梁(台) & 全体重量(t) \\
\cline { 1 - 3 } ウェプクランプ & \multirow{2}{*}{124} & \multirow{2}{*}{448} & \multirow{2}{*}{376} & 約 480 \\
\cline { 1 - 2 } & & & & 約 490 \\
\hline 従来溶接 & & &
\end{tabular}

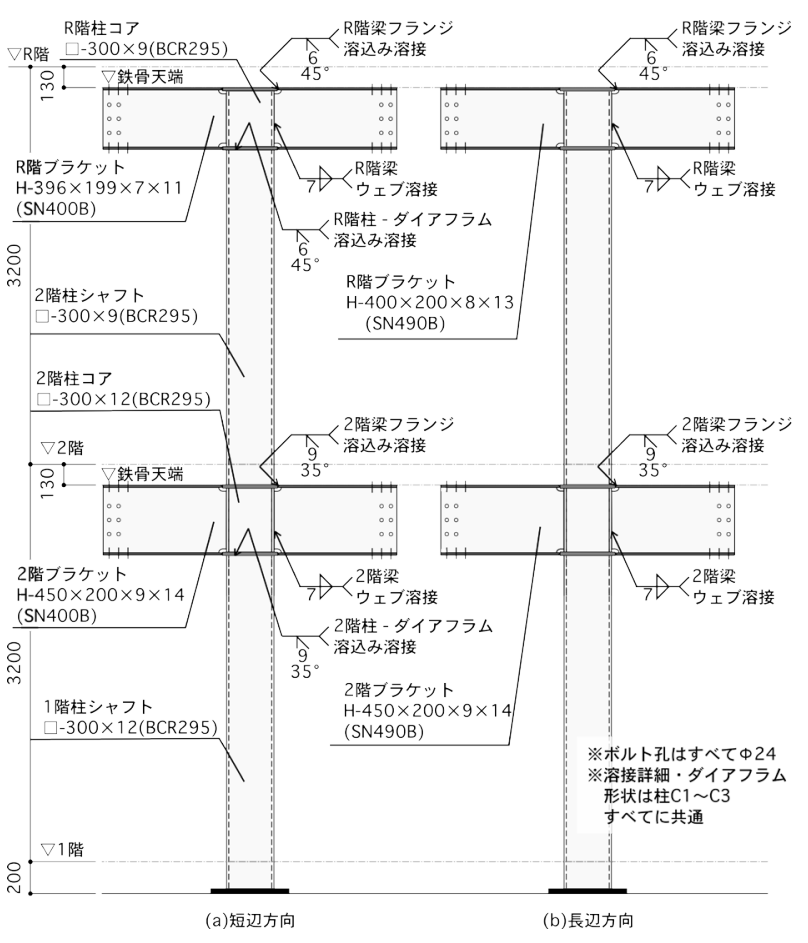

図 6 柱 CA に設ける従来溶接形式柱梁接合部の概要

\section{3 梁製作の概要}

前述のように、梁の製作については、従来溶接形式柱梁接合部と ウェブクランプ形式柱梁接合部とで製作工程に違いがないため、本 報告では梁製作については報告しないこととする。

\section{4. 柱梁接合部の製作時間の比較}

\section{1 ウェブクランプ形式柱梁接合部の製作時間}

鉄骨加工工場および接合金物製作工場では、複数の部材あるいは 複数物件の部材を同時並行で製作しているため、単純に作業開始か ら完了までの時間を本物件にかかった所要時間とみなすことが出来 ない。そこで本報では、各工程の作業について、各部材ごと、また は単位作業量ごとの作業時間を算出し、それに部材数を乗じること により、建物全体の柱梁接合部にかかった製作時間を算出すること とした。

表 4 および表 5 には、表 1 に示した柱 $\mathrm{C} 1$ 〜 $\mathrm{C} 3$ に設けるウェブクラ ンプ形式柱梁接合部の製作時間をまとめたものである。前述のよう 
に、従来溶接形式柱梁接合部とウェブクランプ形式柱梁接合部で柱 脚部分の製作には大きな違いがないため、同表に示した製作時間は 2 階と R 階の柱梁接合部の製作にかかるもののみであり、柱脚部分の 製作時間は含まれていない。

まず表 4 には、 2 章 2.2 で示したウェブクランプ形式柱梁接合部の 製作のそれぞれの工程の単位作業時間を示した。単位作業時間は、 実際に本物件を製作した鉄骨加工工場の日ごとの加工出来高を精査 し、同表に示した単位作業にかかった時間に分解したもので、専用 機が必要な加工であれば作業者 1 名と専用機 1 台、専用機が不要な作 業であれば作業者 1 名にて単位作業を行った場合の時間とした。。

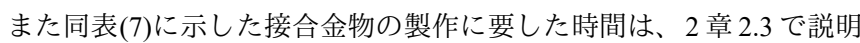
した鋼板の加工から溶接までを含めた製作時間となっており、これ についても実際に接合金物の製作を行った工場の加工出来高を精査 し、(1)〜(6)の各工程と同じ方法で算出した。

つぎに表 5 には、柱 $\mathrm{C} 1 \sim \mathrm{C} 2$ の柱梁接合部の製作に必要な工数を示 すとともに、工数と表 4 に示した単位作業時間の積を示した。同表 にはあわせて、各工程の製作時間の合計を示し、これを柱 $\mathrm{C} 1 \sim \mathrm{C} 2$ に 設ける 2 階と R 階の柱梁接合部の総製作時間とした。

\section{2 従来溶接形式柱梁接合部の製作時間}

表 6 および表 7 は、表 2 に示した柱 $\mathrm{CA} \sim \mathrm{CC}$ に設ける従来溶接形 式柱梁接合部の製作時間をまとめたもので、ウェブクランプ形式柱 梁接合部の製作時間を示した表 4 および表 5 に相当するものである。

表 6 および表 7 の表記方法は、前節に示したウェブクランプ形式柱 梁接合部の製作時間をまとめた表 4 および表 5 と同様である。ただし 実際には従来溶接形式柱梁接合部を適用した製作は行われていない ので、次の方法で算出した推定值を示している。主に従来形式柱梁 接合部の加工を行っている鉄骨加工工場にヒアリングを行い、本報 が対象とした物件と柱梁断面、ダイアフラムサイズが近いものの実 績值を調査し、これから表 6 に示した単位作業時間を推定した。こ れに工数を乗じて柱一台あたりの製作時間を算出し表 7 に示した。 表 6 に示した単位作業時間は表 4 に示したウェブクランプ形式柱梁接 合部の単位作業時間と同様に、専用機が必要な加工であれば作業者 1 名と専用機 1 台で製作を行い、専用機が不要な作業は作業者 1 名にて 単位作業を行った場合の時間である。

\section{3 両形式柱梁接合部の製作時間の比較}

表 8 には、表 5 および表 7 に示したウェブクランプ形式柱梁接合部 および従来溶接形式柱梁接合部の各柱の製作時間から、本報で対象 とした物件で製作する全ての柱梁接合部の製作時間をまとめたもの である。同表をみると、ウェブクランプ形式柱梁接合部の場合は 1625 時間であるのに対して、従来溶接形式柱梁接合部は 2421 時間で ある。この製作時間について詳細に分析するために、図 7 にはウェ ブクランプ形式柱梁接合部および従来溶接形式柱梁接合部のそれぞ れについて、表 8 に示した柱梁接合部の総製作時間を(1)開先・切断 作業、(2)組立作業、(3)溶接作業、および(4)検査・仕上作業の 4 種類 に分解したものを示した。ただしウェブクランプ形式柱梁接合部の 場合においては、接合金物と柱の製作をわけており、上記の 4 種類 の作業に加えて接合金物の製作作業を加えた 5 種類を示した。

同図をみると、ウェブクランプ形式柱梁接合部の製作では、従来 溶接形式柱梁接合部で必要な製作作業すべてにおいて製作時間の短 縮が達成できていることがわかる。
表 4 各工程における作業時間（ウェブクランプ）

\begin{tabular}{|c|c|c|c|}
\hline 番号 & 工程 & 単位作業時間 & 算出条件 \\
\hline (1) & 孔加工 - 切断 - 開先 & 柱一台あたり $1.6 \mathrm{~h}$ & $\begin{array}{c}\text { 専用孔あけ、切断、開先 } \\
\text { 加工機 } 1 \text { 台 }\end{array}$ \\
\hline (2) & 長孔加工 & 長孔 1 カ所あたり $0.1 \mathrm{~h}$ & ポータブルガス切断機 1 台 \\
\hline (3) & 羁書き & 柱 1 台あたり 1.0h & \multirow{4}{*}{ 作業者 1 名 } \\
\hline (4) & 組立 & 柱 1台あたり 1.6h & \\
\hline (5) & 溶接・仕上げ溶接 & 換算溶接長※ $8.3 \mathrm{~m} / \mathrm{h}$ & \\
\hline (6) & 仕上·矯正作業 & 柱一台あたり $1.6 \mathrm{~h}$ & \\
\hline (7) & 接合金物製作 & 1セットあたり $0.67 \mathrm{~h}$ & 2 章 2.3 記載加工機各 1 台 \\
\hline
\end{tabular}

※換算溶接長は文献 8)により算出した溶接長である

表 5 柱 1 台あたりの各工程の工数と製作時間 (ウェブクランプ)

\begin{tabular}{|c|c|c|c|c|c|c|}
\hline \multirow{2}{*}{$\begin{array}{l}\text { 表 } 4 \\
\text { 番号 }\end{array}$} & \multicolumn{2}{|c|}{$\mathrm{C} 1$} & \multicolumn{2}{|c|}{$\mathrm{C} 2$} & \multicolumn{2}{|c|}{ C3 } \\
\hline & 工数 & 時間(h) & 工数 & 時間(h) & 工数 & 時間(h) \\
\hline (1) & 1 台 & $1.6 \mathrm{~h}$ & 1 台 & $1.6 \mathrm{~h}$ & 1台 & $1.6 \mathrm{~h}$ \\
\hline (2) & 12 力所 & $1.2 \mathrm{~h}$ & 6 力所 & $0.6 \mathrm{~h}$ & 12 力所 & $1.2 \mathrm{~h}$ \\
\hline (3) & 1 台 & $1.0 \mathrm{~h}$ & 1 台 & $1.0 \mathrm{~h}$ & 1台 & $1.0 \mathrm{~h}$ \\
\hline (4) & 1 台 & $1.6 \mathrm{~h}$ & 1台 & $1.6 \mathrm{~h}$ & 1台 & $1.6 \mathrm{~h}$ \\
\hline (5) & $23.9 \mathrm{~m} ※$ & $2.9 \mathrm{~h}$ & $19.2 \mathrm{~m} \approx$ & $2.4 \mathrm{~h}$ & $24.8 \mathrm{~m} ※$ & $3.0 \mathrm{~h}$ \\
\hline (6) & 1台 & $1.6 \mathrm{~h}$ & 1台 & $1.6 \mathrm{~h}$ & 1 台 & $1.6 \mathrm{~h}$ \\
\hline (7) & 6セット & $4.0 \mathrm{~h}$ & 3セット & $2.0 \mathrm{~h}$ & 6セット & $4.0 \mathrm{~h}$ \\
\hline 計 & & $13.9 \mathrm{~h}$ & & $10.8 \mathrm{~h}$ & & $14.0 \mathrm{~h}$ \\
\hline
\end{tabular}

表 6 各工程における作業時間（従来溶接）

\begin{tabular}{|c|c|c|c|}
\hline 番号 & 工程 & 単位作業時間 & 算出条件 \\
\hline (A) & 柱切断 - 開先 & 1 力所あたり $0.375 \mathrm{~h}$ & 専用切断. 開先機 1 台 \\
\hline (B) & ブラケット切断・開先 & ブラケット 1 台 $0.3 \mathrm{~h}$ & 専用切断·開先機 1 台 \\
\hline (C) & コア組立 & コア1台あたり $1.33 \mathrm{~h}$ & 作業者 1名 \\
\hline (D) & コア溶接 & 換算溶接長 ※ $20 \mathrm{~m} / \mathrm{h}$ & ロボット溶接機 1 台 \\
\hline (E) & コア - ブラケット仕口組立 & コア1台あたり $1.33 \mathrm{~h}$ & \multirow{3}{*}{ 作業者 1名 } \\
\hline (F) & コア - ブラケット仕口溶接 & 換算溶接長 $※ 10 \mathrm{~m} / \mathrm{h}$ & \\
\hline (G) & 大組立 & 柱 1 台あたり $1.4 \mathrm{~h}$ & \\
\hline$(\mathrm{H})$ & 大組溶接 & 換算溶接長 $※ ~ 20 \mathrm{~m} / \mathrm{h}$ & ロボット溶接機 1 台 \\
\hline (I) & UT & 1 力所あたり $0.04 \mathrm{~h}$ & \multirow{2}{*}{ 作業者 1 名 } \\
\hline$(\mathrm{J})$ & 仕上·矯正作業 & 柱一台あたり 1.6h & \\
\hline
\end{tabular}

表 7 柱 1 台あたりの各工程の工数と製作時間 （従来溶接）

\begin{tabular}{|c|c|c|c|c|c|c|}
\hline \multirow{2}{*}{$\begin{array}{l}\text { 表6 } \\
\text { 番号 }\end{array}$} & \multicolumn{2}{|c|}{$\mathrm{CA}$} & \multicolumn{2}{|c|}{ CB } & \multicolumn{2}{|c|}{$\mathrm{CC}$} \\
\hline & 工数 & 時間(h) & 工数 & 時間(h) & 工数 & 時間(h) \\
\hline (A) & 7 力所 & $2.5 \mathrm{~h}$ & 7 力所 & $2.5 \mathrm{~h}$ & 7 力所 & $2.5 \mathrm{~h}$ \\
\hline (B) & 8 力所 & $2.4 \mathrm{~h}$ & 6 力所 & $1.6 \mathrm{~h}$ & 4 力所 & $1.2 \mathrm{~h}$ \\
\hline (C) & 2 台 & $2.7 \mathrm{~h}$ & 2台 & $2.7 \mathrm{~h}$ & 2台 & $2.7 \mathrm{~h}$ \\
\hline (D) & $27.3 \mathrm{~m} ※$ & $1.4 \mathrm{~h}$ & $22.3 \mathrm{~m} ※$ & $1.2 \mathrm{~h}$ & $22.3 \mathrm{~m} *$ & $1.1 \mathrm{~h}$ \\
\hline (E) & 2 台 & $2.7 \mathrm{~h}$ & 2 台 & $2.7 \mathrm{~h}$ & 2 台 & $2.7 \mathrm{~h}$ \\
\hline (F) & $29.0 \mathrm{~m} ※$ & $2.9 \mathrm{~h}$ & $21.8 \mathrm{~m} ※$ & $2.2 \mathrm{~h}$ & $14.5 \mathrm{~m} *$ & $1.5 \mathrm{~h}$ \\
\hline (G) & 1 台 & $1.4 \mathrm{~h}$ & 1 台 & $1.4 \mathrm{~h}$ & 1 台 & $1.4 \mathrm{~h}$ \\
\hline (H) & $19.2 \mathrm{~m} ※$ & $1.0 \mathrm{~h}$ & $16.8 \mathrm{~m} ※$ & $0.8 \mathrm{~h}$ & $16.8 \mathrm{~m} ※$ & $0.8 \mathrm{~h}$ \\
\hline (I) & 44 力所 & $1.8 \mathrm{~h}$ & 40 力所 & $1.6 \mathrm{~h}$ & 36 力所 & $1.5 \mathrm{~h}$ \\
\hline$(\mathrm{J})$ & 1 台 & $1.6 \mathrm{~h}$ & 1台 & $1.6 \mathrm{~h}$ & 1台 & $1.6 \mathrm{~h}$ \\
\hline 計 & & $20.4 \mathrm{~h}$ & & $18.3 \mathrm{~h}$ & & $17.0 \mathrm{~h}$ \\
\hline
\end{tabular}

まず開先・切断および組立にかかった時間をみると、開先・切断 にかかった時間は 4 割程度、組立にかかった時間は 6 割程度短縮して いる。これらの作業時間が短縮したひとつの理由としては、次のよ うな両接合部の部材構成の違いが考えられる。従来溶接形式柱梁接 合部では図 6 に示したように、柱はコア、シャフト、ダイアフラム およびブラケットといった部材で構成されており、開先・切断作業 ではそれぞれの小口に開先加工を行い、また組立作業ではジグ等を 用いて精度を確保しつつ部材を組立て、組立溶接を行う。これに対 しウェブクランプ形式柱梁接合部では、柱単材に補強板・ガセット プレート類を取り付けるのみであるため、開先加工が少なく、また 補強板類の取付は高い精度を必要としないものであるため、組立作 業ではジグが不要で容易であったものと思われる。柱単材に各部品 を取り付けていくという特徵は、ウェブクランプ形式柱梁接合部だ けでなく、スプリットティ形式やエンドプレート形式など、他の乾 式柱梁接合工法に共通しているので、このような省工程化による製 
作時間の短縮は、他の乾式柱梁接合工法にもあてはまると考えられ る。

次に溶接にかかった時間に着目する。グラフをみるとウェブクラ ンプ形式柱梁接合部により 4 割程度溶接時間が短縮している。従来 溶接形式柱梁接合部の溶接時間が長いのは、完全溶込み溶接が多い ため溶接量が多く、これに時間を要するためである。確かに、ほと んどがロボット溶接で行われることを想定すれば、作業者の実働時 間としてはこれほどの違いはない可能性もあるが、表 5 の項目(5)あ るいは表 7 の項目 $(\mathrm{D})(\mathrm{F})(\mathrm{H})$ に示した溶接量の違いは明白であり、 ウェブクランプ形式柱梁接合部を始めとする乾式柱梁接合工法を有 効に活用すれば、省資源、省エネルギーにも貢献できるものと思わ れる。

仕上・検査にかかった時間もほぼ半減している。これは従来溶接 形式柱梁接合部では、すべての柱梁接合部に完全溶け込み溶接が存 在し、これが応力伝達メカニズム上重要な機能を果たしているため UT が必須となる一方で、ウェブクランプ形式柱梁接合部では隅肉溶 接しかなく、かつ応力伝達のほとんどが高力ボルト摩擦接合部分で 行われるため、UT が不要であるためである。

一方ウェブクランプ形式柱梁接合部では、接合金物製作時間が余 計に加わることになり、これが全体製作時間のおよそ3割弱を占め る。しかしそれ以外の加工にかかる時間は従来溶接形式柱梁接合部 と比較してほぼ半減しているため、全体としても従来溶接形式柱梁 接合部の 7 割弱の時間で製作出来たことがわかる。

\section{5. まとめ}

本報では、乾式柱梁接合工法のひとつとしてウェブクランプ形式 柱梁接合部に着目し、本接合部を用いた実施物件を通して、柱梁接 合部の製作に必要な作業と時間を算出した。その後、この実施物件 を梁ブラケットを工場で溶接接合する従来溶接形式柱梁接合部で再 設計し、設計断面及び各部部材サイズから、本物件に従来溶接形式 柱梁接合部用いた場合に予想される柱梁接合部の製作時間を算出し た。両形式柱梁接合部の製作時間の比較を通して、ウェブクランプ 形式柱梁接合部の接合部製作における特徵を把握した。

検討の結果、開先・切断・孔あけ、組立、溶接および仕上・検査 のすべての工程で 4 割以上の作業時間の短縮が確認され、接合金物 の製作時間を含めても、ウェブクランプ形式柱梁接合部の全体の製 作時間は従来溶接形式柱梁接合部の場合と比べて短縮した。

上記に示したウェブクランプ形式柱梁接合部による接合部製作時 間が短縮した要因は、溶接量が少なくUT 部がない点、また柱単材に 補強板を取り付ける組立を行う点であると考えられる。これらの特 徵は他の乾式柱梁接合工法に共通するため、他の乾式柱梁接合工法 を用いても程度の差はあれど接合部製作時間の短縮が期待できる。

なお本報で検討した物件は梁せいが最大 $450 \mathrm{~mm}$ と比較的小さく、 また低層の建物である。これが高層となり梁せいも大きくなると、 ウェブクランプ形式柱梁接合部においては接合に使用する接合金物 の形状や、柱補強する補強板のディテールが変わるため、柱梁接合 部の製作時間やその短縮の程度が大幅に異なる。このような物件規 模、または柱梁接合部ディテールが異なる場合における、ウェブク ランプ形式柱梁接合部と従来溶接形式柱梁接合部の製作方法・製作 時間の違いについては、次報以降にて検討したい。
表 8 接合部の総製作時間の比較

\begin{tabular}{|c|c|c|c|c|}
\hline 接合部 & 柱タイプ & 加工時間 $(\mathrm{h})$ & 台数(台) & 合計(h) \\
\hline \multirow{3}{*}{ ウェブクランプ } & $\mathrm{C} 1$ & 13.9 & 84 & 1167.6 \\
\cline { 2 - 5 } & $\mathrm{C} 2$ & 10.8 & 32 & 345.6 \\
\cline { 2 - 5 } & $\mathrm{C} 3$ & 14.0 & 8 & 112.0 \\
\hline \multirow{3}{*}{ ウェブクランプ形式柱梁接合部 製作時間合計 } & 1625.2 \\
\hline \multirow{2}{*}{ ウ } & $\mathrm{CA}$ & 20.4 & 80 & 1632.0 \\
\cline { 2 - 5 } & $\mathrm{CB}$ & 18.3 & 32 & 585.6 \\
\cline { 2 - 5 } & $\mathrm{CC}$ & 17.0 & 12 & 204.0 \\
\hline
\end{tabular}

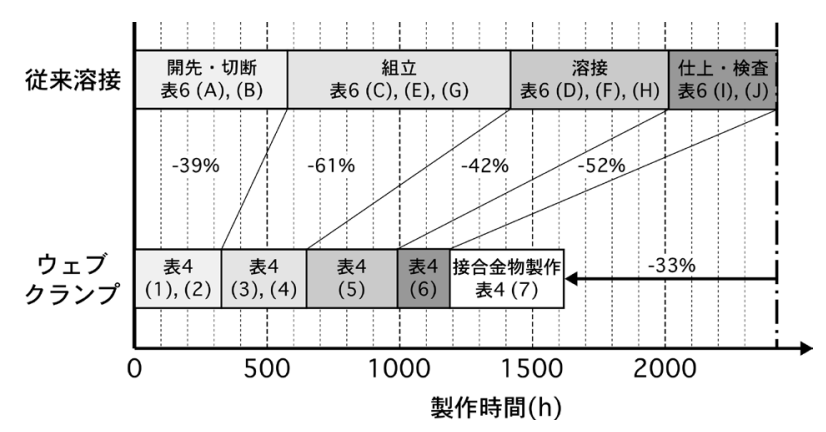

図 7 柱梁接合部製作の作業内容別の比較

\section{謝辞}

従来溶接形式柱梁接合部を用いた本報告対象物件の設計において は、雄健工業株式会社設計部各位の多大なる協力を得ました。また、 本報告に用いた生産・製作・施工の記録については、大川スティー ル株式会社および株式会社キーテクノロジー関係各位の多大なる協 力を得ました。ここに記して謝意を表します。

\section{参考文献}

1) 日本建築学会 : 鋼構造接合部設計指針, 日本建築学会, 2012.3

2) 荒木 景太, 伊山 潤, 朴 世万: ウェブクランプ柱梁接合形式における仕口部 断面の応力分担に関する考察 ウェブクランプ形式柱梁接合部に関する研 究その 1, 日本建築学会構造系論文集, Vol.79, No.706,pp.1931-1940, 2014.12

3) 長谷川智, 丹治郁夫, 小高清孝: 女川原子力発電所第 3 号機における太径パド ル工法を用いた施工について, 日本建築学会大会学術講演梗概集(中国), 21588, pp.1175-1176, 1999.9

4) 與田香二，増田浩志ほか: 鉄骨造平屋骨組における柱梁接合部の合理化に関 する実験的研究: (その 1)梁端高力ボルト摩擦接合部の提案, 日本建築学会大 会学術講演梗概集(北海道), 22423, pp. 845-846, 2013.8

5) 日本鋼構造協会:鋼構造技術総覧[建築編], 技報堂出版, 1998.4

6) 藤本奈美, 多賀謙藏ほか: 高力ボルト接合による柱梁接合部の有用性に関す る研究, 日本建築学会大会学術講演梗概集(九州), 22645, pp.1289-1290, 2016.8

7) 崔彰訓, 伊藤拓海ほか: 鉄骨低層建物における接合部の生産性に関する研究 その 2 嵌合式接合方法と柱梁剛接合方法の作業時間の比較, 日本建築学会大 会学術講演梗概集(中国), 8112,pp.223-224, 2017.7

8) 社団法人鉄骨建設業協会: 鉄骨溶接延長換算表 改訂版, 2004.7

[2018 年 10 月 3 日原稿受理 2018 年 12 月 17 日採用決定］ 